\title{
POLE Gene Mutation
}

National Cancer Institute

\section{Source}

National Cancer Institute. POLE Gene Mutation. NCI Thesaurus. Code C131797.

A change in the nucleotide sequence of the POLE gene. 